\title{
Effect of Different Pressing Processes and Density on Dimensional Stability and Mechanical Properties of Bamboo Fiber-based Composites ${ }^{1}$
}

\author{
Ya-Hui Zhang ${ }^{2} \cdot$ Yu-Xiang Huang ${ }^{2} \cdot$ Hong-Xia $\mathrm{Ma}^{3} \cdot$ Wen-Ji Yu ${ }^{2} \cdot$ Yue Qi(D) ${ }^{2, \dagger}$
}

\begin{abstract}
In this study, the dimensional stability and mechanical properties of bamboo fiber-based composites (BFBCs) were studied at two pressing manufacturing processes, i.e., hot- and cold- pressing, and were compared with three density parameters $\left(1.0,1.1\right.$, and $\left.1.2 \mathrm{~kg} / \mathrm{m}^{3}\right)$. Width swelling ratio (WSR), thickness swelling ratio (TSR), and water absorption ratio (WAR) were calculated for water immersions of 4 and $28 \mathrm{~h}$. WSR, TSR, and WAR for specimens immersed for $28 \mathrm{~h}$ were higher than those for $4 \mathrm{~h}$ treatment, which shows that the immersion time has a significant influence on the dimensional stabilities of BFBCs. Moreover, the positive linear relations between density and dimensional were observed at both the pressing ways, indicating that the WSR, TSR, and WAR decreased with an increase in the density of BFBCs. The compressive strength, shear strength, modulus of rupture (MOR), and modulus of elasticity (MOE) were determined. The compressive strength, MOR, and MOE of hot-pressed specimens were significantly higher than those for the cold-pressed specimens, which are also directly proportional to density. Moreover, the samples with the highest density of $1.2 \mathrm{~kg} / \mathrm{m}^{3}$ performed high values on mechanical properties in both the manufacturing methods.
\end{abstract}

Keywords: cold pressing, density, dimensional stability, hot pressing, mechanical properties

\section{INTRODUCTION}

Bamboo has fast growth rotation owing to its light weight and high tensile strength in comparison with other species of wood (Roh et al., 2004; Roh, 2007). Bamboo is widely utilized for the industry, construction, furniture, household equipment, and handicrafts (Maulana et al., 2017). Bamboo composites, such as plywood and strand board, have attracted a significant amount of attention of the researchers (Lee et al., 1996; Lee et al., 2000). So far, bamboo has been used in several industrial manufacturing processes. Thus, bamboo-based composites are important for improving both the quality of manufacturing and production and also in research and development (John and Thomas, 2008; John et al., 2008).

However, considering the advantages of bamboo and its productivity, one of the most promising usages is

\footnotetext{
${ }^{1}$ Date Received February 1, 2018, Date Accepted July 4, 2018

${ }^{2}$ Key Lab Wood Science \& Technology, State Forestry Administration, Research Institute of Wood Industry, Chinese Academy of Forestry, Xiang Shan Road, Haidian 100091, Beijing China

${ }^{3}$ Guangdong Academy of Forestry, 510520, Guangzhou China

† Corresponding author: Yue Qi (e-mail: qiyue1219@caf.ac.cn, ORCID: 0000-0002-8205-2685)
} 

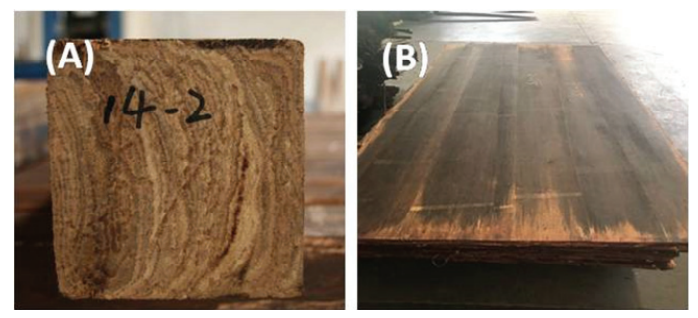

Fig. 1. (A): Block BFBCs and (B): Plank BFBCs.

to manufacture the composite by crushing and fluffing bamboo mat and recombining them. In previous researches (Yu et al., 2015; Zhang et al., 2016), bamboo composites were manufactured with high strength, large scale, and natural texture. Thus, the bamboo composite could be used in the field of engineering and decoration.

Currently, hot- and cold-pressing are two bamboo composite manufacturing techniques. These techniques differ with respect to the curing method and product dimension (Fig. 1). However, the bamboo composites manufactured by both the pressing ways can be applied in construction, flooring, and decoration. Thus, in this study, for evaluating the influence of pressing method and density on bamboo fiber-based composites
(BFBCs), the mechanical properties and dimensional stabilities were determined and compared.

\section{MATERIALS and METHODS}

\subsection{Materials}

The bamboo species, namely Phyllostachys heterocycla (P. heterocycla), were obtained from south China. Liquid phenolic formaldehyde (PF) adhesive (Dynea Chemical Industry Co., Ltd., Guangdong, China) was used for composite manufacturing with a solid content of $44.2 \%$.

\subsection{Manufacture processing}

The bamboo culms with the moisture contents of $8 \%-10 \%$ were split into several strips and were then produced into oriented bamboo fiber mat (OBFM) via a fluffing machine (Guosen, Qingdao, China). The dimensions of the average length, width, and thickness were 2,000, 100-200, and 2-5 mm, respectively.

The obtained OBFMs were carbonized for $2 \mathrm{~h}$ and

Table 1. Effect of different pressing methods on dimensional stabilities of BFBCs at 4 and $28 \mathrm{~h}$ water immersion

\begin{tabular}{|c|c|c|c|c|c|c|c|}
\hline \multirow[b]{2}{*}{ method } & \multirow{2}{*}{$\begin{array}{l}\text { Density } \\
\left(\mathrm{kg} / \mathrm{m}^{3}\right)\end{array}$} & \multicolumn{3}{|c|}{$4 \mathrm{~h}$} & \multicolumn{3}{|c|}{$28 \mathrm{~h}$} \\
\hline & & $\begin{array}{c}\text { WSR } \\
(\%)\end{array}$ & $\begin{array}{l}\text { TSR } \\
(\%)\end{array}$ & $\begin{array}{c}\text { WAR } \\
(\%)\end{array}$ & $\begin{array}{c}\text { WSR } \\
(\%)\end{array}$ & $\begin{array}{l}\text { TSR } \\
(\%)\end{array}$ & $\begin{array}{c}\text { WAR } \\
(\%)\end{array}$ \\
\hline \multirow{3}{*}{ Hot-pressed } & 1.0 & $\begin{array}{l}0.55^{\mathrm{A}} \\
(0.01)\end{array}$ & $\begin{array}{l}4.03^{\mathrm{A}} \\
(0.20)\end{array}$ & $\begin{array}{l}5.32^{\mathrm{A}} \\
(0.09)\end{array}$ & $\begin{array}{l}0.79^{\mathrm{A}} \\
(0.01)\end{array}$ & $\begin{array}{l}6.70^{\mathrm{A}} \\
(0.17)\end{array}$ & $\begin{array}{l}6.18^{A} \\
(0.22)\end{array}$ \\
\hline & 1.1 & $\begin{array}{l}0.46^{\mathrm{B}} \\
(0.01)\end{array}$ & $\begin{array}{l}3.75^{\mathrm{AB}} \\
(0.05)\end{array}$ & $\begin{array}{l}4.94^{\mathrm{B}} \\
(0.15)\end{array}$ & $\begin{array}{c}0.68^{\mathrm{B}} \\
(0.01)\end{array}$ & $\begin{array}{l}4.78^{\mathrm{B}} \\
(0.09)\end{array}$ & $\begin{array}{l}5.08^{\mathrm{B}} \\
(0.18)\end{array}$ \\
\hline & 1.2 & $\begin{array}{l}0.27^{\mathrm{C}} \\
(0.01)\end{array}$ & $\begin{array}{c}2.5^{\mathrm{C}} \\
(0.03) \\
\end{array}$ & $\begin{array}{l}4.29^{\mathrm{C}} \\
(0.04)\end{array}$ & $\begin{array}{l}0.49^{\mathrm{C}} \\
(0.01)\end{array}$ & $\begin{array}{l}3.54^{\mathrm{C}} \\
(0.05)\end{array}$ & $\begin{array}{l}4.21^{\mathrm{C}} \\
(0.09)\end{array}$ \\
\hline \multirow{3}{*}{ Cold-pressed } & 1.0 & $\begin{array}{l}1.69^{\mathrm{A}} \\
(0.13)\end{array}$ & $\begin{array}{l}2.95^{\mathrm{A}} \\
(0.01)\end{array}$ & $\begin{array}{l}8.25^{\mathrm{A}} \\
(0.05)\end{array}$ & $\begin{array}{l}2.54^{\mathrm{A}} \\
(0.12)\end{array}$ & $\begin{array}{l}3.74^{\mathrm{A}} \\
(0.04)\end{array}$ & $\begin{array}{l}8.91^{\mathrm{A}} \\
(0.03)\end{array}$ \\
\hline & 1.1 & $\begin{array}{l}1.37^{\mathrm{B}} \\
(0.09)\end{array}$ & $\begin{array}{l}2.47^{\mathrm{B}} \\
(0.06)\end{array}$ & $\begin{array}{l}7.04^{\mathrm{B}} \\
(0.13)\end{array}$ & $\begin{array}{l}1.89^{\mathrm{B}} \\
(0.06)\end{array}$ & $\begin{array}{l}2.94^{\mathrm{B}} \\
(0.01)\end{array}$ & $\begin{array}{l}7.33^{\mathrm{B}} \\
(0.02)\end{array}$ \\
\hline & 1.2 & $\begin{array}{l}0.96^{\mathrm{C}} \\
(0.05)\end{array}$ & $\begin{array}{l}1.48^{\mathrm{C}} \\
(0.12)\end{array}$ & $\begin{array}{l}5.21^{\mathrm{C}} \\
(0.08)\end{array}$ & $\begin{array}{l}1.78^{\mathrm{B}} \\
(0.05)\end{array}$ & $\begin{array}{l}1.78^{\mathrm{C}} \\
(0.02)\end{array}$ & $\begin{array}{l}5.11^{\mathrm{C}} \\
(0.14)\end{array}$ \\
\hline
\end{tabular}

Note: The numbers in parenthesis are the standard deviation. Means within a column followed by the same capital letter are not significantly different at 5\% significance level using Duncan's test. 


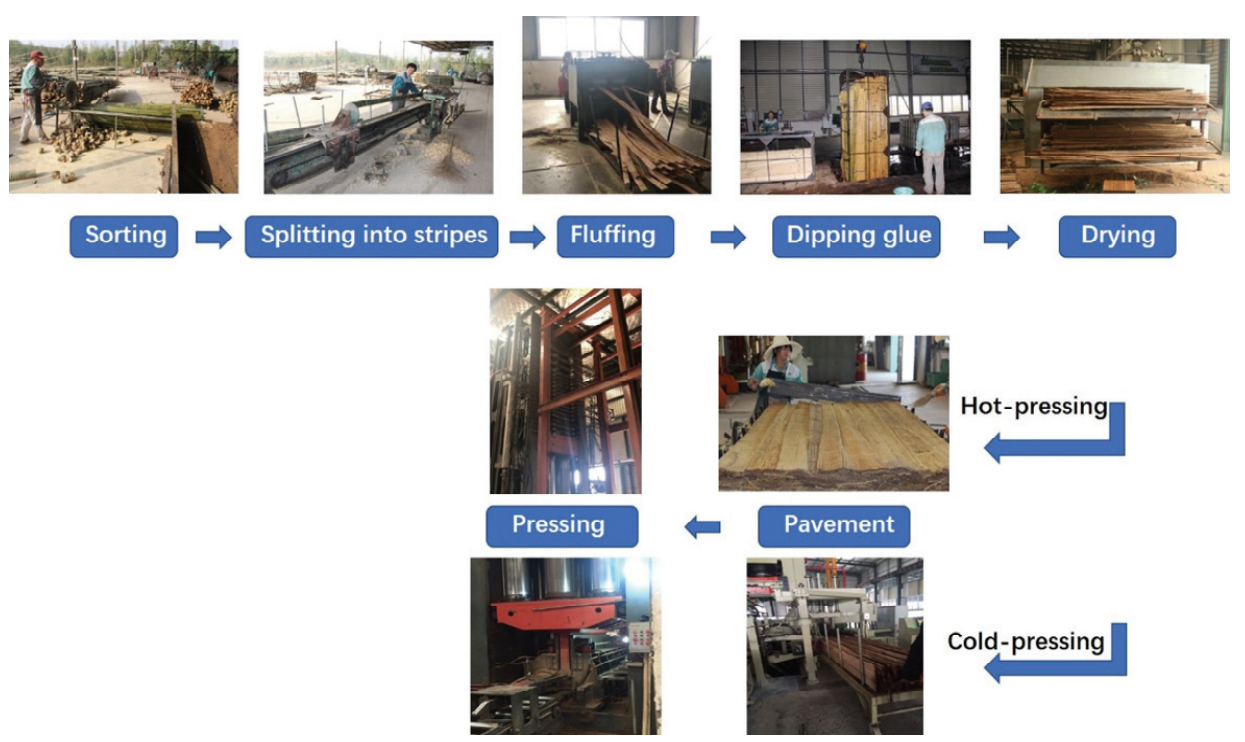

Fig. 2. Manufacturing of BFBCs with two pressing methods.

were totally impregnated in PF adhesive with a $12 \%$ solid content for $10 \mathrm{~min}$. The moisture content in impregnated OBFMS was controlled at approximately $8 \%-10 \%$ via oven drying for $12 \mathrm{~h}$. Then, the prepared materials were hot-pressed at $145^{\circ} \mathrm{C}$ at a rate of 1.0 $\mathrm{mm} / \mathrm{min}$. For cold pressing, the glued OBFMs were laid and pressed in a chamber (Fig. 2) and then were transmitted on the curing device for $14 \mathrm{~h}$ at $135{ }^{\circ} \mathrm{C}$. The curing duration of manufacturing was $14 \mathrm{~h}$. After completing the above processes, the obtained BFBCs were placed at ambient temperature for cooling. The BFBC density was determined by measuring its air-dry weight and volume after the composites were kept in a conditioning room with a relative humidity of 65 $\pm 3 \%$ at $25{ }^{\circ} \mathrm{C} \pm 2{ }^{\circ} \mathrm{C}$ for 2 weeks. After measurement, the samples with exact densities of 1.0, 1.1, and 1.2 $\mathrm{kg} / \mathrm{m}^{3}$ were selected for evaluating properties.

\subsection{Property evaluation}

Mechanical properties were tested using a universal testing machine (WDW-W10, Time Co., Ltd., Jinan,
China). The samples with dimensions of $450 \mathrm{~mm}$ (length) $\times 24 \mathrm{~mm}$ (width) $\times 20 \mathrm{~mm}$ (thickness) were used to measure the modulus of rupture (MOR) and modulus of elasticity (MOE) according to GB/T 17657 (2013). Compressive strength and shear strength (perpendicular to loading) were measured with the dimensions of $120 \mathrm{~mm}$ (length) $\times 40 \mathrm{~mm}$ (width) $\times$ $20 \mathrm{~mm}$ (thickness) and $80 \mathrm{~mm}$ (length) $\times 20 \mathrm{~mm}$ (width) $\times 20 \mathrm{~mm}$ (thickness) in accordance with ASTM D 3501 (2005) and GB/T 20241 (2006), respectively.

For the evaluation of dimensional stability, the thickness swelling ratio (TSR), width swelling ratio (WSR), and water absorption ratio (WAR) were evaluated and calculated using the following equations:

$$
\operatorname{TSR}(\%)=100 \times(\mathrm{T} 2-\mathrm{T} 1) / \mathrm{T} 1,
$$

where $\mathrm{T} 1$ and $\mathrm{T} 2$ represent the thickness of the specimens before and after water immersion treatment, respectively.

$$
\text { WSR }(\%)=100 \times(\mathrm{W} 2-\mathrm{W} 1) / \mathrm{W} 1 \text {, }
$$


where W1 and W2 represent the width of the specimens before and after water immersion treatment, respectively.

WAR $(\%)=100 \times($ WA2 - WA1 $) / W A 1, \cdots(2)$

where WA1 and WA2 represent the weight of the specimens before and after water immersion test, respectively.

The entire measurements were followed by immersion in boiling water for $4 \mathrm{~h}$, oven drying at $63^{\circ} \mathrm{C}$ for $20 \mathrm{~h}$, and finally re-immersion in boiling water for $4 \mathrm{~h}$ according to Chinese national standards GB/T 30364 and GB/T 20241. All the measurements were repeated for at least five times.

\subsection{Statistical analysis}

Differences in the physical and mechanical properties among samples with different densities were statistically examined with a one-way ANOVA and post-hoc Duncan tests (IBM SPSS ver. 21, USA).

\section{RESULTS and DISCUSSION}

\subsection{Dimensional stability and water absorption}

The data on the dimensional change of BFBCs are presented in Table 1. The swelling of all samples increased with an increase in the water immersion time from $4 \mathrm{~h}$ to $28 \mathrm{~h}$ due to the decrease of internal stress and the interfacial failure between the resin and OBFMs. For $4 \mathrm{~h}$ immersion, the WSR of BFBCs decreased with an increase in the density from 1.0 to $1.2 \mathrm{~kg} / \mathrm{m}^{3}$. In comparison with the WSR, TSR of all the specimens pressed with two ways showed significant variation. With an increase in the density, the TSR value of hot-pressed specimens decreased from $4.03 \%$ to $2.5 \%$; whereas, for cold-pressed specimens, it decreased from $2.95 \%$ to $1.48 \%$. For $28 \mathrm{~h}$ immersion, the WSR of hot-pressed specimens decreased from $0.79 \%$ to $0.49 \%$, and that of cold-pressed specimens decreased from $2.54 \%$ to $1.78 \%$. Moreover, a similar trend in the density variation was observed for the WSR and TSR value in $28 \mathrm{~h}$ water immersion. Notably, the swelling ratio decreased with the increasing density of BFBCs, which can be attributed to the reduction in the internal void volume. As a result, the water penetration into the layer or cell wall is obstructed.

WA percentages for both the manufacturing methods are shown in Table 1. With an increase in the water immersion time, WA also increased during hot- and cold-pressing processes, which can be attributed to an increase in the broken ratio of the adhesive layer. Moreover, WA of the specimens with a density of 1.20 $\mathrm{kg} / \mathrm{m}^{3}$ is lowest due to the crushed abundant parenchyma cells and the cells were penetrated and covered by the resin, thus hindering water penetration (Chung and Wang, 2018). Consequently, the high-density BFBC with low porosity has a positive influence on WA reduction. The WA reduction could be attributed to the decreased porosity in the BFBCs. Meanwhile, the WSR and WA values of hot-pressed specimens are significantly lower than those for cold-pressed specimens, whereas high TSR values were observed in the hot-pressed specimens at 4 and $28 \mathrm{~h}$ water immersion. The difference between two pressing ways might be related to the different pressing durations, temperature or even pavement direction. Overall, regardless of the pressing method used, the results in the measurement of dimensional stability have been up to the standard of GB/T 30364 (2013) and GB/T 20241 (2006). Upon comparing both the pressing methods, detailed information is provided for the manufacturing factory. Thus, an optimal way can be selected according to the requirement of products or industrial conditions. 
Effect of Different Pressing Processes and Density on Dimensional Stability and Mechanical Properties of Bamboo Fiber-based Composites

\subsection{Mechanical properties}

The mechanical properties of the experimental materials are displayed in Table 2. The compressive strength of specimens significantly improved with an increase in density for both two pressing methods. The compressive strengths of hot-pressed specimens are 116.12, 137.10, and 147.62 $\mathrm{MPa}$, and that for the cold-pressed specimens are 110.9, 122.06, and 125.22 MPa. These results could be related to an increase in the fiber amount or compression ratio with an increase in the density. With BFBCs of the same thickness, the addition of fiber amount could lead to a high compression ratio. Moreover, as the compression ratio increased, the bonding point would be increased to join the adhesive with bamboo fiber. Thus, the density has a significant influence on the compressive strength. With respect to the shear strength, a slight increase is observed in the hot-pressed specimens with an increase in the density, and the shear strength of specimens in cold-pressed condition has almost the same values. Zhu et al. (2015) examined that the shear strength of $P$. heterocycla BFBCs was 17.98 MPa with a density of $1.15 \mathrm{~kg} / \mathrm{m}^{3}$. However, for the cold-pressed BFBCs, no significant influence of density was observed on shear strength. The results revealed that the hot-pressed BFBCs had a significantly higher value of MOR and MOE than cold-pressed specimens (Table 2). The MOR and MOE values in hot-pressed specimens showed a similar trend as in the cold-pressed specimens, which slightly increased with an increase in the density, according to the ANOVA test. The MOR values ranged from 180.37 to $187.00 \mathrm{MPa}$ in hot pressing and from 162.33 to $175.96 \mathrm{MPa}$ in cold pressing. Moreover, the MOE values in hot pressing ranged from 17,047.33 to $17,915.00 \mathrm{MPa}$ with a density ranging from 1.0 to $1.2 \mathrm{~kg} / \mathrm{m}^{3}$, whereas it was $16,487.5$ to $17,675.33 \mathrm{MPa}$ in cold-pressed specimens. The previous studies noted that the PF resin acts as a low molecular weight prepolymer and determines the degree of polymerization during curing (Rowell, 1991; Zhu and Yu, 2011).

Table 2. Mechanical properties of BFBCs with two pressing methods

\begin{tabular}{|c|c|c|c|c|c|}
\hline $\begin{array}{l}\text { Manufacturing } \\
\text { method }\end{array}$ & $\begin{array}{l}\text { Density } \\
\left(\mathrm{kg} / \mathrm{m}^{3}\right)\end{array}$ & $\begin{array}{c}\text { Compressive } \\
\text { Strength (MPa) }\end{array}$ & $\begin{array}{c}\text { Shear strength } \\
(\mathrm{MPa})\end{array}$ & MOR (MPa) & MOE(MPa) \\
\hline \multirow{3}{*}{ Hot-pressed } & 1.0 & $\begin{array}{c}116.12^{\mathrm{A}} \\
(1.46)\end{array}$ & $\begin{array}{l}20.99^{\mathrm{A}} \\
(0.32)\end{array}$ & $\begin{array}{c}180.37^{\mathrm{A}} \\
(0.31)\end{array}$ & $\begin{array}{c}17047.33^{\mathrm{A}} \\
(50.64)\end{array}$ \\
\hline & 1.1 & $\begin{array}{c}137.10^{\mathrm{B}} \\
(2.13)\end{array}$ & $\begin{array}{c}21.54^{\mathrm{AB}} \\
(0.21)\end{array}$ & $\begin{array}{c}185.63^{\mathrm{B}} \\
(0.07)\end{array}$ & $\begin{array}{c}17870.33^{\mathrm{B}} \\
(30.21)\end{array}$ \\
\hline & 1.2 & $\begin{array}{c}147.62^{\mathrm{C}} \\
(1.20)\end{array}$ & $\begin{array}{l}22.18^{\mathrm{B}} \\
(0.08)\end{array}$ & $\begin{array}{c}187.00^{\mathrm{B}} \\
(2.05)\end{array}$ & $\begin{array}{c}17915.00^{\mathrm{B}} \\
(98.45)\end{array}$ \\
\hline \multirow{3}{*}{ Cold-pressed } & 1.0 & $\begin{array}{c}111.90^{\mathrm{A}} \\
(1.33)\end{array}$ & $\begin{array}{l}20.58^{\mathrm{A}} \\
(0.05)\end{array}$ & $\begin{array}{c}162.33^{\mathrm{A}} \\
(1.59)\end{array}$ & $\begin{array}{c}16487.50^{\mathrm{A}} \\
(101.30)\end{array}$ \\
\hline & 1.1 & $\begin{array}{c}122.06^{\mathrm{B}} \\
(0.50)\end{array}$ & $\begin{array}{l}20.62^{\mathrm{A}} \\
(0.17)\end{array}$ & $\begin{array}{c}164.88^{\mathrm{A}} \\
(0.97)\end{array}$ & $\begin{array}{c}16681.00^{\mathrm{B}} \\
(50.10)\end{array}$ \\
\hline & 1.2 & $\begin{array}{c}125.22^{\mathrm{C}} \\
(0.85)\end{array}$ & $\begin{array}{l}20.85^{\mathrm{B}} \\
(0.03)\end{array}$ & $\begin{array}{c}175.96^{\mathrm{B}} \\
(2.45)\end{array}$ & $\begin{array}{c}17675.33^{\mathrm{C}} \\
(20.77)\end{array}$ \\
\hline
\end{tabular}

Note: The numbers in parenthesis are the standard deviation. Means within a column followed by the same capital letter are not significantly different at $5 \%$ significance level by using Duncan's test. 


\section{CONCLUSION}

This study investigated and compared the properties of BFBCs. The dimensional stability improved with an increase in the density. Moreover, at the same density level, the value of WSR, TSR, and WAR was low in hot-pressed BFBCs, whereas compressive strength, MOR and MOE perfromed higher values in the specimens for hot pressing method. However, a significant difference was observed between different pressing processes. In addition, for the selection of the pressing method, the demands of products and factory condition should also be considered. Therefore, the data in this study provided the detailed information for the industrial manufacturing.

\section{ACKNOWLEDGMENT}

This study was financially supported by the Fundamental Research Funds of the Chinese Academy of Forestry (CAF) CAFYBB2017QA015.

\section{REFERENCES}

ASTM D3501 Standard test method for wood-based structural panels in compression.

ASTM International, West Conshohocken, PA, 2005.

Chung, M.J., Wang, S.Y. 2018. Mechanical properties of oriented bamboo scrimber boards made of Phyllostachys pubescens (moso bamboo) from Taiwan and China as a function of density. Holzforschung 72(2): 151-158.

GB/T 17657. 2013. Test methods of evaluating the properties of wood-based panels and surface decorated wood-based panels. Standardization Administration of China, Beijing, China.

GB/T 20241. 2006. "Laminated veneer lumber," Standardization Administration of China, Beijing, China.
GB/T 30364. 2013. "Bamboo scrimber flooring," Standardization Administration of China, Beijing, China.

John, M.J., Thomas, S. 2008. Biofibres and Biocomposites. Carbohydrate Polymers 71(3): 343-364.

John, M.J., Francis, B., Varughese, K.T., Thomas, S. 2008. Effect of Chemical Modification on Properties of Hybrid Fiber Biocomposites. Composites Part A: Applied Science and Manufacturing 39(2): 352-363.

Maulana, S., Busyra, I., Fatrawana, A., Hidayat, W., San, R.K., Sumardi, I., Wistara, I.N.J., Lee, S.H., Kim, N.H., Febrianto, F. 2017. Effects of steam treatment on physical and mechanical properties of bamboo oriented strand board. Journal of the Korean Wood Science and Technology 45(6): 872-882.

Roh, J.K., Kim, J.K., Kim, S.I., Ra, J.B., Kim, Y.J., Park, S.J. 2004. Manufacture of wood veneerbamboo zephyr composite board-I. Properties of bamboo zephyr and composite board made from Moso, Giant Timber and Hachiku bamboo. Journal of the Korean Wood Science and Technology 32(3): 42-51.

Roh, J.K. 2007. Manufacture of Wood Veneer-Bamboo Zephyr Composite Board: II. Effect of Manufacturing Conditions on Properties of Composite Board. Journal of the Korean Wood Science and Technology 35(6): 108-117.

Rowell, R.M. 1991. Chemical modification of wood. In: Hon, D.N.S., Shiraishi, N. (eds.), Handbook on wood and cellulosic material. Marcel Dekker, Inc., New York, pp. 703-756, Chapter 15.

Yu, Y.L., Huang, X.A., Yu, W.J. 2014. A novel process to improve yield and mechanical performance of bamboo fiber reinforced composite via mechanical treatments. Composites Part B 56: 48-53.

Yu, Y.L., Zhu, R.X., Wu, B.L., Hu, Y.A., Yu, W.J. 
Effect of Different Pressing Processes and Density on Dimensional Stability and Mechanical Properties of Bamboo Fiber-based Composites

2015. Fabrication, material properties, and application of bamboo scrimber. Wood Science Technology 49(1): 83-98.

Zhang, Y.H., Zhang, Y.M., Ren, D.H., Yu, W.J. 2016. Effect of Manufacturing technology on Scrimber Performance. China Wood Industry 30(5): 31-34. Zhu, R.X., Yu, W.J. 2011. Effect of density on physical and mechanical properties of reconstituted small- sized bamboo fibrous sheet composite. Advanced Materials Research 150: 634-639.

Zhu, R.X., Zhang, Y.H., Yu, W.J. 2015. Outdoor exposure tests of bamboo-fiber reinforced composite: evaluation of the physical and mechanical properties after two years. European Journal of Wood and Wood Products 73(2): 275-278. 